\title{
Lyme Neuroborreliosis (LNB) - Clinical and Diagnostic Difficulties
}

\author{
Lyme Neuroborrelioza (LNB) - trudności kliniczne i diagnostyczne
}

\author{
Dorota Dunin-Wąsowicz', Beata Kasztelewicz², Katarzyna Tomaszek', Alicja Pawińska², \\ Janusz Książyk ${ }^{3}$, Anna Wieteska-Klimczak ${ }^{3}$, Elżbieta Jurkiewicz ${ }^{4}$, Katarzyna Dzierżanowska-Fangrat ${ }^{2}$ \\ ${ }^{1}$ Neurology and Epileptology Department The Children's Memorial Health Institute Warsaw, Poland \\ ${ }^{2}$ Microbiology and Immunology Department The Children's Memorial Health Institute Warsaw, Poland \\ ${ }^{3}$ Pediatric, Nutrition and Metabolic Diseases Department The Children's Memorial Health Institute Warsaw, Poland \\ ${ }^{4}$ Department of Diagnostic Imaging The Children's Memorial Health Institute Warsaw, Poland \\ DOI:10.20966/chn.2017.53.406
}

\section{STRESZCZENIE}

Cel: Zastosowanie metody RT-PCR dla wykrywania DNA Borrelia burgdorferi w płynie mózgowo-rdzeniowym u pacjentów pediatrycznych z różnymi objawami neurologicznymi i podejrzeniem choroby z Lyme. Materiał i metody: Badanie prospektywne przeprowadzono u 107 dzieci w wieku od 1-18 lat (średnio 12.2 lat). Badania serologiczne we krwi przeprowadzano dwuetapowo - test ELISA, a następnie test Western blot. W próbkach płynu mózgowo-rdzeniowego wykonywano test ELISA oraz badanie metodą RT-PCR celem potwierdzenia lub wykluczenia rozpoznania neuroboreliozy (LNB). U wszystkich pacjentów wykonywano badania neurologiczne, okulistyczne i neuroobrazowe. Wyniki: U 60 (56.1\%) dzieci stwierdzono dodatnie wyniki przeciwciał IgG i/lub IgM w surowicy i/lub w płynie mózgowo-rdzeniowym. Tylko u 2/60 (3.3\%) wykryto DNA Borrelia burgdorferi PMRDz oraz specyficzne przeciwciała w surowicy i w płynie mózgowo-rdzeniowym (przypadki LNB - aseptyczne zapalenie opon mózgowo-rdzeniowych z TIA oraz zapalenie nerwu II I nerwu VI). LNB zdiagnozowano u 33 pacjentów a u 22/107 (20.5\%) rozpoznano choroby demielinizacyjne. U dzieci z LNB stwierdzono statystycznie znamiennie wyższe miana lgG w PMRDz i wyniki testu Western blot $-\lg \mathrm{p}$ (chi2 $>9.333$ ) $=0.0023$, WB- $p$ (chi2 $>12.941)=0.0003$. Wnioski: Wykrycie DNA Borrelia burgdorferi w PMRDz przy użyciu metody RT-PCR może być pomocne dla potwierdzenia diagnozy wczesnej LNB. Negatywne wyniki DNA Borrelia burgdorferi w PMRDz są szczególnie ważne dla wykluczenia LNB i przydatne dla ustalenia rozpoznania chorób demielinizacyjnych. Kuracja Ceftraksonem podawanym dożylnie przez 4 tygodnie jest skuteczna w leczeniu neuroinfekcji, eliminacji DNA Borrelia burgdorferi z płynu mózgowo-rdzeniowego i poprawy klinicznej pacjentów.

Słowa kluczowe: neuroborelioza, płyn mózgowo-rdzeniowy, metoda RT-PCR, choroby demielinizacyjne
ABSTRACT

Aim: Assessment of clinical utility of Borrelia burgdorferi DNA detection in cerebrospinal fluid (CSF) and urine using RT-PCR method in pediatric patients with different neurological signs and symptoms and suspicion of Lyme disease. Material and methods: Prospective study was carried out in 107 children aged 1-18 (mean 12.2 ) years. Serological tests in blood were performed in two-step approach - ELISA followed by Western blot. ELISA test was performed on CSF samples as well as RT-PCR method for confirmation or exclusion of Lyme neuroborreliosis (LNB) diagnosis. All patients underwent neurological, ophtalmological and neuroimaging examinations. Results: In 60 (56.1\%) children IgG and/or IgM Borrelia antibodies were positive in serum and/or CSF. Only in 2/60 (3.3\%) Borrelia burgdorferi DNA was found in CSF with specific antibodies detected in serum and CSF - (LNB - aseptic meningitis with TIA and nerve II and $\mathrm{VI}$ neuritis cases). LNB was diagnosed in 33 patients and in 22/107(20.5\%) demyelinating diseases. IgG in CSF, Western blot test results were significantly higher in children with LNB $\lg \mathrm{p}($ chi2 $>9.333)=0.0023$, WB- $\mathrm{p}($ chi2 $>12.941)=0.0003$. Conclusions: Detection of DNA Borrelia burgdorferi in CSF using RT-PCR method might be helpful for confirmation of early LNB diagnosis. Negative results for DNA Borrelia burgdorferi in CSF are especially important for exclusion of LNB and useful for establishment of demyelinating diseases diagnosis. Four-week intravenous Ceftriaxone course is sufficient for LNB neuroinfection treatment, elimination of DNA Borrelia burgdorferi from CSF and clinical improvement of patients.

Key words: neuroborreliosis, cerebrospinal fluid, RT-PCR method, demyelinating diseases

\section{INTRODUCTION}

Tickborne spirochaetes of the Borrelia burgdroferi sensu lato genospecies cause Lyme disease. For many years Lyme neuroborreliosis (LNB) has been known as a frequent $(14 \%$ $34 \%$ or $40 \%$ ) manifestation of Lyme disease [1, 2]. Symptoms of LNB are not characteristic and typical for LNB only but may often mimic other neurological diseases. Diagnosis of LNB is based on clinical presentation of different neuro- logical signs and symptoms supported by laboratory tests including cerebrospinal (CSF) examination. Serological tests are recommended for diagnosis of Lyme disease. IgM and IgG antibodies may be absent in some patients with early LNB. Positive or negative values of serological tests depend on assay performance and on prevalence of the disease in population. Therefore LNB diagnosis could be difficult. CSF examination is crucial for LNB diagnostic procedures. 
However, direct methods (culture techniques and qualitative and quantitative PCR) are not available and recommended for routine LNB diagnosis [3-6].

Aim: Assessment of clinical utility of Borrelia burgdorferi DNA detection in CSF and urine using RT-PCR method in pediatric patients with suspicion of LNB.

\section{MATERIAL AND METHODS}

Prospective study was carried out in 107 children (62$57.9 \%$ girls, $45-42.1 \%$ boys) aged $1-18$ years (mean 12.2 years) between July 2013 and April 2017.

In all patients with different neurological signs and symptoms and suspicion of LNB, serology in blood, CSF

and real-time PCR method in CSF and urine were performed. Serological tests in blood were performed in twostep approach involving screening test (Borrelia recombinant IgG/IgM ELISA, Biomedica) followed by Western blot (Borrelia NB IgM/IgG recomblot, Mikrogen Diagnostic) for reactive and equivocal serum samples (i.e. $\geq$ $11 \mathrm{BBU} / \mathrm{ml})$. ELISA test was performed on CSF samples (samples suspected for LNB with values $\geq 5 \mathrm{BBU} / \mathrm{ml}$ ).

Real-time PCR method was used for detection Borrelia burgdorferi sensu lato DNA in CSF and urine. Total bacterial DNA was extracted from clinical specimens (CSF or urine) using a commercial kit (QIAamp DNA mini Kit, Qiagen, Inc., Valencia, CA). The clinical samples were pre-processed as follows: $2 \mathrm{~mL}$ of urine or $1 \mathrm{ml}$ of CSF sample was centrifuged (at $11000 \mathrm{rpm}$ for $20 \mathrm{~min}$ ) to a final volume of $200 \mu \mathrm{L}$ (sample concentration). An internal standard (IS) was added directly into the concentrated sample at the beginning of the DNA extraction process. The extraction was done according to the manufacturer's specifications (blood and body fluid spin protocol) with the final elution volume of $50 \mu \mathrm{L}$. Following DNA extraction realtime PCR was performed using GeneProof Borrelia burgdorferi PCR Kit (GeneProof, Czech Republic) on the 7500 real-time PCR System (applied Biosystmes) according to the manufacturer's protocol. Two controls: positive (Borrelia burgdorferi DNA) and negative (no template control) were included in each run. The $95 \%$ assay reproductivity cutoff was 0.532 copies $/ \mu \mathrm{L}$. Assay specificity includes genospecies: B. burgdorferi sensu stricto, B. andersoni, B. bissetti, B. garini, B. afzeli, B. valaisiana, B. lusitaniae, B. japonica, B. tanukii, B. turdi, B. sinica.
All patients underwent neurological, ophtalmological examination and brain and/or spinal cord magnetic resonance imaging (MRI). The study protocol was approved by local Bioethics Committee.

\section{STATISTICAL ANALYYIS}

STATISTICA 10 (t-Student test for continuous, $\mathrm{chi}^{2}$ test for non-continuous variables, and $\mathrm{p}$ value of $<0.05$ was considered as statistically significant).

\section{RESULIS}

1. Exclusion of Lyme disease and other clinical diagnostic results

In 47 (43,9\%) children specific serological tests in blood, CSF and Borrelia burgdorferi sensu lato DNA in CSF and urine were negative. In these patients, Lyme disease LNB was excluded. Demyelinating diseases diagnosis can be definitely established in 15 out of 47 children. Other 32 out of 47 patients had bacterial menigitis, sepsis, HSV -1 and HCMV neuroinfection, myelitis, Mellkerson-Rosenethal, Miller-Fisher syndromes, headaches, ataxia caused by neuroblastoma, polyneuritis of the cranial nerves (nerves III,VI,VII), ADEM, cerebrovascular malformations.

\section{Serological and RT-PCR results}

In $60(56.1 \%)$ children with clinically suspected neuroborreliosis, IgG and/or IgM Borrelia specific antibodies were positive in serum and/or CSF (by ELISA and Western blot tests). In 45 out of 60 patients (75\%), Borrelia specific antibodies were positive in serum only. In 38 (63.4\%) patients, IgM Borrelia specific antibodies were diagnosed in serum and CSF. Only in 2/60 (3.3\%) Borrelia burgdorferi sensu lato DNA using RT-PCT method was found in CSF (10 days after the onset of symptoms) and also specific antibodies were detected in serum and CSF (tab. I). RT-PCR results for Borrelia sensu lato in urine were negative in all 107 patients (patient's urine was investigated during the same hospitalization as examination of the serum and CSF).

\section{Patients with positive RT-PCR borrelial DNA results in CSF}

In one 15 year old male (patient No1) with positive RTPCR result (borrelial DNA $>0.532$ copies $/ \mu \mathrm{L}$ ) in CSF only serum $\mathrm{IgG}$ antibodies $(43 \geq 11 \mathrm{BBU} / \mathrm{ml})$ but no serum IgM were found. In this adolescent antibodies values $-\mathrm{IgG}$ $(51 \geq 5 \mathrm{BBU} / \mathrm{ml})$ and $\operatorname{IgM}(7 \geq 5 \mathrm{BBU} / \mathrm{ml})$ were higher in $\mathrm{CSF}$

Table I. Positive serological and RT-PCR results for Borrelia burgdorferi in 60/107 (56.1\%) patients Tabela I. Dodatnie wyniki serologiczne i RT-PCR dla Borrelia burgdorferi u 60/107 (56.1\%) pacjentów

\begin{tabular}{lcccc}
\hline & Serum only & Serum + CSF & Serum+CSF+ DNA Borrelia CSF(+) & Total \\
\hline $\operatorname{lgG}$ only & 7 & 4 & $\mathbf{1}^{*}$ & $12(20 \%)$ \\
\hline $\operatorname{lgM}$ only & 34 & 4 & 0 & $38(63.4 \%)$ \\
\hline $\lg +\lg M$ & 4 & 5 & $\mathbf{1}^{* *}$ & $10(16.6 \%)$ \\
\hline Total & $45(75 \%)$ & $13(21.7 \%)$ & $2(3.3 \%)$ & $60(100 \%)$ \\
\hline
\end{tabular}

$1 *$ (serum $\lg G+, \lg M-), \operatorname{CSF}(\lg G+, \lg M+)$

1 * (surowica $\lg G+, \lg M-)$, $P M R D z(\lg G+, \lg M+$ )

$1 * *($ serum $\lg G+, \lg M+), \operatorname{CSF}(\lg G+, \lg M+)$

$1^{* *}($ surowica $\lg G+, \lg M+), P M R D z(\lg G+, \lg M+)$ 
than in serum. Antibody index (AI) $\operatorname{IgG}$ value was 1.18. CSF analysis in patient Nol revealed elevated pleocytosis (63 cell/ $\mu \mathrm{L})$, protein level $(102 \mathrm{mg} / \mathrm{dL})$ and low glucose concentration $(16 \mathrm{mg} / \mathrm{dL})$. Patient Nol suffered from severe headache with paraesthesia and dysaesthesia in upper right limb with motoric and sensoric aphasia symptoms for one hour and additionally transient, few minute vision disturbances, also somnolence and vomiting. Diagnosis of LNB (aseptic meningitis with transient ischemic attackTIA) was established (tab. II).
In a 7-year-old boy (patient No2) with Borrelia burgdorferi sensu lato, DNA detected in CSF both $\mathrm{IgG}$ and IgM antibodies were found in serum and in CSF. In patient No 2 specific antibodies values in serum were as follows: IgG $23 \geq 11$ $\mathrm{BBU} / \mathrm{ml}$,IgM 24>11BBU $/ \mathrm{ml}$ and in CSF :IgG 32>5BBU $/ \mathrm{ml}$, $\operatorname{IgM} 12 \geq 5 \mathrm{BBU} / \mathrm{ml}$. AI IgG value was 1.39 , and AI IgM-0.5.In patient No2, cerebrospinal analysis was normal (pleocytosis 2 cell/dL, protein level $24 \mathrm{mg} / \mathrm{dL}$ ) and he demonstrated right ocular strabismus and vision disturbances. In patient No2 diagnosis of LNB with nerve II and VI neuritis was established.

Table II. Clinical and microbiological characteristic of 33 patients with LNB (group A) (part 1 and 2)

Tabela II. Charakterystyka kliniczna i mikrobiologiczna 33 pacjentów z LNB ( grupa A) (część 1 i 2)

\begin{tabular}{|c|c|c|c|c|c|c|c|c|c|c|}
\hline & $\begin{array}{l}\text { Serum } \\
\text { only } \\
\text { IgG }\end{array}$ & $\begin{array}{l}\text { Serum } \\
\text { only } \\
\text { IgIM }\end{array}$ & $\begin{array}{l}\text { Serum } \\
\text { only } \\
\lg G \\
\lg M\end{array}$ & $\begin{array}{l}\text { Serum } \\
\text { and } \\
\text { CSF } \\
\operatorname{Ig} G\end{array}$ & $\begin{array}{l}\text { Serum } \\
\text { and } \\
\text { CSF } \\
\text { IgM }\end{array}$ & $\begin{array}{c}\text { Serum } \\
\text { and } \\
\text { CSF } \\
\lg G \\
\lg M\end{array}$ & $\begin{array}{c}\text { Serum } \\
\text { IgG } \\
\text { and CSF } \\
\text { IgG } \\
\text { and DNA } \\
\text { Borrelia } \\
\text { in CSF }\end{array}$ & $\begin{array}{c}\text { Serum } \\
\text { IgM } \\
\text { and CSF } \\
\text { IgM } \\
\text { and DNA } \\
\text { Borrelia } \\
\text { in CSF }\end{array}$ & $\begin{array}{c}\text { Serum } \\
\text { IgG IgM } \\
\text { and } \\
\text { CSF } \\
\text { IgG IgM } \\
\text { and DNA } \\
\text { Borrelia } \\
\text { in CSF }\end{array}$ & $\begin{array}{l}\text { Total } \\
\text { (\% of } \\
\text { LNB) }\end{array}$ \\
\hline $\begin{array}{l}\text { Aseptic meningitis } \\
\text { with myelitis }\end{array}$ & 0 & 0 & 0 & 1 & 0 & 0 & 0 & 0 & 0 & $1(3.03 \%)$ \\
\hline $\begin{array}{l}\text { Aseptic meningitis } \\
\text { with cerebellitis }\end{array}$ & 0 & 1 & 0 & 0 & 0 & 0 & 0 & 0 & 0 & $1(3.03 \%)$ \\
\hline $\begin{array}{l}\text { Aseptic meningitis } \\
\text { with nerve VII } \\
\text { peripheral palsy(PFNP) }\end{array}$ & 0 & 0 & 0 & 0 & 0 & 1 & 0 & 0 & 0 & $1(3.03 \%)$ \\
\hline $\begin{array}{l}\text { Aseptic meningitis } \\
\text { with TIA } \\
\text { (Patient No1) }\end{array}$ & 0 & 0 & 0 & 0 & 0 & 0 & 0 & 0 & $\begin{array}{l}1 *(\text { serum } \\
\lg G+, \lg M-)\end{array}$ & $1(3.03 \%)$ \\
\hline Encephalitis & 0 & 1 & 0 & 0 & 0 & 0 & 0 & 0 & 0 & $1(3.03 \%)$ \\
\hline $\begin{array}{l}\text { Encephalitis with nerve } \\
\text { II neuritis }\end{array}$ & 0 & 1 & 0 & 0 & 0 & 0 & 0 & 0 & 0 & $1(3.03 \%)$ \\
\hline ADEM & 0 & 0 & 0 & 1 & 1 & 0 & 0 & 0 & 0 & $2(6.06 \%)$ \\
\hline Total & 0 & 3 & 0 & 2 & 1 & 1 & 0 & 0 & 1 & $8(24.2 \%)$ \\
\hline
\end{tabular}

\begin{tabular}{|c|c|c|c|c|c|c|c|c|c|c|}
\hline Neuritis -nerve II & 1 & 0 & 0 & 0 & 0 & 0 & 0 & 0 & 0 & $1(3.03 \%)$ \\
\hline Neuritis -nerve II and VII & 0 & 1 & 0 & 0 & 0 & 0 & 0 & 0 & 0 & $1(3.03 \%)$ \\
\hline $\begin{array}{l}\text { Neuritis -nerve II } \\
\text { and VI (Patient No 2) }\end{array}$ & 0 & 0 & 0 & 0 & 0 & 0 & 0 & 0 & 1 & $1(3.03 \%)$ \\
\hline $\begin{array}{l}\text { Nerve VII peripheral } \\
\text { palsy (PFNP) }\end{array}$ & 3 & 3 & 0 & 0 & 1 & 2 & 0 & 0 & 0 & $9(27.3 \%)$ \\
\hline GBS syndrome & 0 & 2 & 0 & 0 & 0 & 0 & 0 & 0 & 0 & $2(6.06 \%)$ \\
\hline Stroke & 0 & 0 & 0 & 1 & 0 & 0 & 0 & 0 & 0 & $1(3.03 \%)$ \\
\hline $\begin{array}{l}\text { Neuritis -peripheral } \\
\text { nerves }\end{array}$ & 1 & 1 & 0 & 0 & 0 & 0 & 0 & 0 & 0 & $2(6.05 \%)$ \\
\hline Banwarth's syndrome & 0 & 0 & 1 & 0 & 0 & 0 & 0 & 0 & 0 & $1(3.03 \%)$ \\
\hline $\begin{array}{l}\text { Headaches with } \\
\text { dizziness and vomits }\end{array}$ & 2 & 2 & 1 & 0 & 1 & 0 & 0 & 0 & 0 & $6(18.2 \%)$ \\
\hline $\begin{array}{l}\text { Concentration and } \\
\text { memory disturbances }\end{array}$ & 0 & 0 & 0 & 0 & 0 & 1 & 0 & 0 & 0 & $1(3.03 \%)$ \\
\hline Total & 7 & 9 & 2 & 1 & 2 & 3 & 0 & 0 & 1 & $25(75.8 \%)$ \\
\hline
\end{tabular}


Brain MRI revealed twisted intraocular nerves containing fluid in the nerves sheath (Figure 1).

Patient No 2 had many $(>10)$ tick bites spirochaetes without erythema migrans, but_patient No1 had none.

Control RT-PCR results for Borrelia DNA in CSF were negative after 4-week treatment with intravenous Ceftriaxone. Urine from patient No1 and No2 was investigated also after antibiotics therapy and the results were negative too.

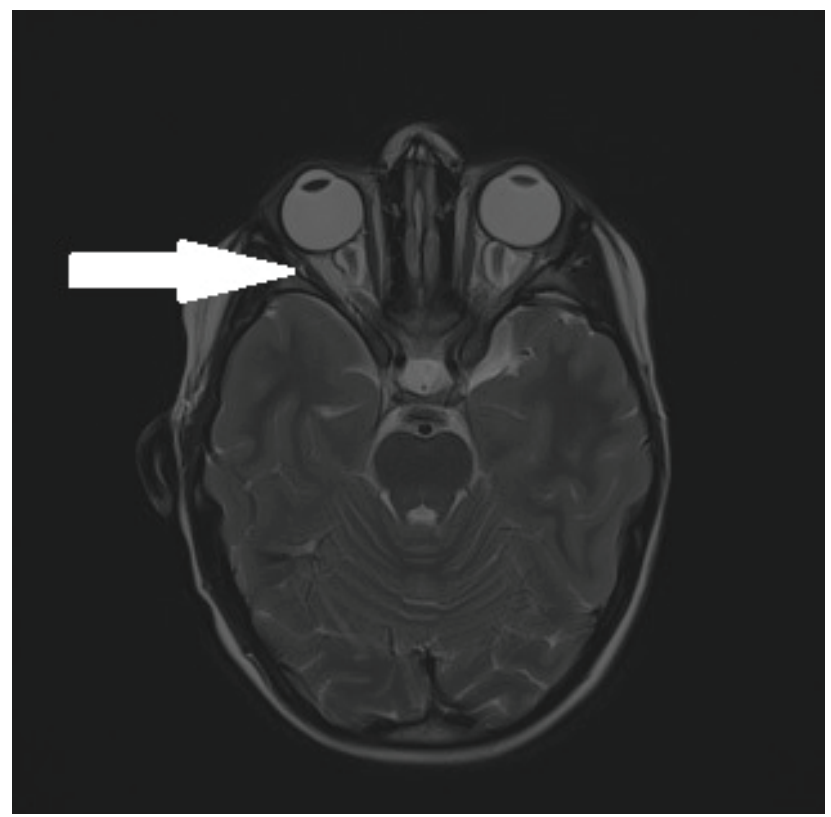

Figure 1. Brain MRI (Patient No 2). (T1 - coronal view) - twisted intraocular nerves containing fluid in the nerves sheath

Ryc. 1. MRI mózgu ( Pacjent Nr 2). (T1- przekrój wieńcowy kręte nerwy wzrokowe z płynem w osłonkach nerwów)

\section{Patients' clinical and microbiological treatment results}

Table II presents characteristic of 33 out of 60 patients (group A) with LNB diagnosis based on clinical, neuroimaging and serological and RT-PCR method results. Peripheral nerve VII palsy (PFNP) in $9(27.3 \%)$ and headaches with dizziness and vomits in $6(18.2 \%)$ were found the most frequently in children with LNB. Aseptic meningitis, encephalitis and ADEM were diagnosed in 8 (24.2\%) patients with LNB. Patient with aseptic meningitis and right nerve VII peripheral palsy had the highest values of IgG AI (2.03) and also IgM AI (2.3). Twenty three patients (23/33$69.7 \%$ ) from group A with LNB were treated with intravenous Ceftriaxone course for 21-28 days and 10/33 (30.3\%) also with additional 2 week oral antibiotics therapy.

Twenty seven (27) out of 60 patients (group B) had positive serological results for borrelial antibodies (1 serum IgG only, 23 serum IgM and 3 serum IgG and IgM). In all 27 children antibodies were negative in CSF and CSF pleocytosis was normal. Nineteen (19/27) children suffered from headaches without vomiting and dizziness caused by borreliosis. Eight (8/27-29.6\%) patients with headaches were treated with 14-21 days intravenous Ceftriaxone course and 5/27-18.5\% also with oral antibiotics for 2 weeks.

One-year-old male from group B had finally established mitochondrial disease diagnosis.

\section{Statistical results}

Western blot results were statistically, significantly higher in group A with LNB than in group B without LNB - p $\left(\mathrm{chi}^{2}>12.941\right)=0.0003$ as well as IgG antibodies in CSF $\mathrm{p}\left(\mathrm{chi}^{2}>9.333\right)=0.0023$ but no IgM antibodies in CSF $\mathrm{p}\left(\mathrm{chi}^{2}>1.492\right)=0.2219$.

Between group A and B there were no statistically significant differences in CSF analysis results of pleocytosis and protein (table III). Pleocytosis in CSF - p $\left(\mathrm{chi}^{2}>3.506\right)$ $=0.061$, protein in CSF $-\mathrm{p}\left(\mathrm{chi}^{2}>0.21\right)=0.650$.

\section{Other results}

Only in one patient No1 with LNB oligoclonal bounds were detected in CSF. Also in all 22 out of 107 (20.6\%) patients with demyelinating diseases oligoclonal bounds were found in CSF.

Fifteen (15/107-14\%) patients had tick-bites including only $3 / 33(9 \%)$ patients from group A with LNB. One fe-

Table III. Comparison of CSF analysis results (pleocytosis and protein level) in group $A$ (LNB) and group $B$ (without LNB)

Tabela III. Porównanie wyników badań PMRDz (peocytoza i stężenie białka) w grupie A ( LNB) I grupie B (bez LNB)

\begin{tabular}{|c|c|c|c|c|c|}
\hline CSF analysis & $\begin{array}{c}\text { Normal pleocytosis } \\
(1-12 / \mu \mathrm{L} \\
\text { mean } 3 / \mu \mathrm{L})\end{array}$ & $\begin{array}{c}\text { Elevated pleocytosis } \\
\qquad \begin{array}{c}(63-503 / \mu \mathrm{L} \\
\text { mean } 138 / \mu \mathrm{L})\end{array}\end{array}$ & $\begin{array}{c}\text { Normal protein } \\
\text { level } \\
(20-40 \mathrm{mg} / \mathrm{dL})\end{array}$ & $\begin{array}{l}\text { Elevated protein level } \\
(50-161 \mathrm{mg} / \mathrm{dL}, \\
\text { mean } 78 \mathrm{mg} / \mathrm{dL})\end{array}$ & Total \\
\hline $\begin{array}{l}\text { Number of patients } \\
\text { - Group A (LNB) }\end{array}$ & $29(87.9 \%)$ & $4^{*}(12.1 \%)$ & $28(84.9 \%)$ & $5^{* *}(15.1 \%)$ & $33(100 \%)$ \\
\hline $\begin{array}{l}\text { Number of patients } \\
\text { Group B (without } \\
\text { LNB) }\end{array}$ & 27 (100\%) & $0(0 \%)$ & $24(88.9 \%)$ & 3 (11.1\%) & 27 (100\%) \\
\hline
\end{tabular}

*Maximum pleocytosis value 503 cells/ $\mu \mathrm{L}$ (467 mononuclear cells/ $\mu \mathrm{L}$ )

*Maksymalna wartość pleocytozy 503 komórek/ $\mu \mathrm{L}$ (467 monocytów/ $\mu \mathrm{L}$ )

** Maximum protein level $161 \mathrm{mg} / \mathrm{dL}$

** Maksymalne stężenie białka $161 \mathrm{mg} / \mathrm{dL}$

No statistically significant differences: pleocytosis in CSF- $p\left(\right.$ chi $\left.^{2}>3.506\right)=0.061$, protein in CSF $-p\left(\right.$ chi $\left.{ }^{2}>0.21\right)=0.650$

Brak różnic istotnych statystycznie: pleocytoza w PMRDz- $\mathrm{p}\left(\mathrm{chi}^{2}>3.506\right)=0.061$, białko w PMRDz- $\mathrm{p}\left(\mathrm{chi}{ }^{2}>0.21\right)=0.650$ 
male adolescent had more than 30 tick-bites and suffered from headaches but no LNB. A few months before diagnostic procedures only one $(1 / 107-0.9 \%)$ patient with headaches without LNB had erythema migrans. Tick-borne encephalitis was diagnosed in one (1/107-0.9\%) 5-year-old female with only positive serum IgM borrelial antibodies.

\section{Patients with demyelinating diseases diagnosis}

Demyelinating diseases diagnosis was finally established in 22 out of $107(25.2 \%)$ patients. In 15 specific serological tests in blood, CSF and Borrelia burgdorferi sensu lato DNA in CSF and urine were negative - 13 patients had multiple sclerosis, 1 neuromyelitis optica-NMO and 1 Balo concentric sclerosis. Multiple sclerosis diagnosis was also established in 7 out of 27 patients from group B with positive serological results for borrelial antibodies.

\section{DISCUSSION}

In patients with neuroborreliosis different form of Borrelia burgdroferi sensu lato were found in neurons and astrocytes [7]. CNS involvement is possible at any stage of Lyme disease and even in patients with erythema migrans [8]. Therefore CSF analysis is crucial for LNB clinical diagnosis. In some patients specific antibodies in serum may occur later than in CSF. At the time of diagnosis in $17 \%$ of patients anti-Borrelia antibodies were found in CSF but not in serum [9]. Diagnosis of early and late LNB based on serological tests and immune response as well differentiation diagnosis with other neurological diseases is sometimes difficult [6-10].

For detection of Borrelia burgorferi sensu lato DNA in body fluid samples (e.g. synovial fluid, blood and also CSF) many PCR-based methods protocols have been developed since 1989 [11-13]. However, in pediatric and adult population, the data concerning borrelial DNA investigation in CSF by different PCR methods are not frequent [14-27]. Sensitivity of the PCR methods for CSF diagnosis in early LNB is relatively low (10-30\%), but could be even lower in late LNB, because spirochaetes can migrate to the different central nervous system tissues [28, 29].

In investigated group only in two patients in early stage of the disease DNA Borrelia burgdorferi was found in CSF using PCR method, also with specific antibodies in CSF and serum. This is additional confirmation of early LNB diagnosis. Patient No1 suffered from aseptic meningitis but also brain vessels involvement with clinical signs and symptoms of TIA. Stroke diagnosed in one patient from investigated group with IgG specific antibodies in CSF and serum was also reported as a sequent of inflammation process caused by spirochaetes Borrelia and even first presentation of Lyme disease [30, 31].

Central nerves involvement, especially nerve VII, is typical for LNB. Patient No 2 had severe optic nerve neuritis, documented in brain MRI. Different ophtalmological manifestation of LNB is also known [32].

Negative control CSF examination using RT-PCR method, as well as complete recovery after four week intravenous Ceftriaxone treatment in patients Nol and No 2, gives a strong evidence that according to the Euro- pean Federation of Neurological Societies (EFNS) guidelines [28] this LNB therapy (14-28 days iv Ceftriaxone) is sufficient.

Peripheral nerve VII palsy (PFNP) was the most frequent clinical sign in patients with LNB, but only one child suffered from aseptic meningitis and peripheral nerve VII palsy. Combination of aseptic meningitis with PFNP was reported more frequently - in $17 \%$ of children [33]. Other cranial nerves involvement was also described as an uncommon manifestation of neuroborreliosis in children [34].

We had diagnosed typical for LNB aseptic meningitis with myelitis and aseptic meningitis with cerebellitis with IgG anti-Borrelia antibodies in CSF and serum and also cases of encephalitis.

Rocha et al. [35] reported a child neuroborreliosis presenting as ADEM and confirmed by PCR method in CSF. However, in our two patients with ADEM diagnosis and LNB DNA Borrelia was not found in CSF, but IgG, IgM antibodies were detected in CSF and serum. We diagnosed two patients with Guillain-Barré syndrome (GBS) and Borrelia infection had been found in GBS [36]. Banwarth's syndrome, peripheral nerves neuritis and concentration and memory disturbances were rarely observed in investigated group. Headaches with dizziness and vomits were frequent in patients with LNB (table II). Less severe headaches were typically observed in investigated patients with borreliosis, but without LNB.

According to the data from literature [3], erythema migrans and tick-bites were also very rare in the study population.

Significantly higher Western blot results in group A with LNB than in group B without LNB and also significantly higher IgG in CSF indicates more intensive and longer inflammation process.

It is well-known that neurological manifestation of Lyme disease and neuroimaging examination results can imitate multiple sclerosis but treatment options and also prognosis are completely different $[37,38]$. Therefore fast differential diagnosis of multiple sclerosis and neuroborreliosis is especially important. In investigated group multiple sclerosis and other demyelinating diseases were diagnosed frequently, not only in patients with totally negative serological and RT-PCR results, but also in patients with positive serology but negative DNA Borrelia burgdorferii in CSF. In these clinical situations negative result RT-PCR method for borrelial DNA in CSF was especially useful for differentiation between both diseases.

In all investigated children, DNA Borrelia burgdorferi using RT-PCR methods were negative in urine. Therefore, according to our data this diagnostic test does not seem to be useful.

Nowadays, laboratory and also clinical diagnosis of Lyme disease and neuroborreliosis still have many traps and challenges $[39,40]$ and need further investigations.

\section{CONCLUSIONS}

1. Detection of DNA Borrelia burgdorferi in CSF using RT-PCR method might be helpful for confirmation of early LNB diagnosis.

2. Negative results for DNA Borrelia burgdorferi in CSF are especially im- 
portant for exclusion of LNB and useful for establishment of demyelinating diseases diagnosis.

3. Four-week intravenous Ceftriaxone course is sufficient for LNB neuroinfection treatment, elimination of DNA Borrelia burgdorferi from CSF and clinical improvement of patients.

\section{REFERENCES}

[1] Cimmino M.A.: Relative frequency of Lyme borreliosis and of its clinical manifestation in Europe. European Community Concerted Action on Risk Assessment in Lyme borreliosis. Infection 1998; 26: 298-300.

[2] Younger D.S.: Epidemiology of Lyme Neuroborreliosis. Neurol Clin 2016; 34: 875-886.

[3] Ornstein K.J., Berglund J., Nilsson I., et al.: Characterization of Lyme borreliosis isolates from patients with erythema migrans and neuroborreliosis in southern Sweden. J Clin Microbiol 2001; 39: 1294-1298.

[4] Ornstein K.J., Berglund J. ,Bergstorm S. et al.: Three major Lyme Borrelia genospecies (Borrelia burgdorferii sensu stricto, B.afzelii and B.garinii) identified in cerebrospinal fluid from patients with neuroborreliosis in Sweden. Scand J Infect Dis 2002; 34: 341-346.

[5] Hansen K, Lebech A.M.: The clinical and epidemiological profile of Lyme neuroborreliosis in Denmark 1985-1990. A prospective study of 187 patients with Borrelia burgdorferi specific intrathecal antibody production. Brain. 1992; 115(Pt 2):399-423 .

[6] Schwenkenbecher P., Pul R., Wurster U. et al.: Common and uncommon neurological manifestation of neuroborreliosis leading to hospitalization. BMC Infect Dis 2017; 17: 90

[7] Miklossy I., Kasas S., ZurnA.D., et al.: Persisting atypical cystic forms of Borrelia burgdorferi and local inflammation in Lyme neuroboreliosis. $J$ Neuroinflamm 2008; 5: 1-18.

[8] Coyle P.K, Schutzer S.E. :Neurologic aspects of Lyme disease. Med Clin. North Am. 2002; 86: 261-284.

[9] Henningsson A.J., Malmawall B.E., Ernerudh A., et al.: Neuroborreliosis an epidemiological, clinical and healthcare cost study from endemic area in the south-east of Sweden. Clin Microbiol Infect 2010; 16: 1245-1251.

[10] Sjowall J., Carlsson A., Vaarala 0., et al.: Innate immune responses in Lyme Borreliosis: enhanced tumor necrosis factor-aipha and interleukin-12 in asymptomatic individuals in response to live spirochetes. Clin Exp Immunol 2005; 141: 89-98.

[11] Schmidt B.L.: PCR in laboratory diagnosis of Borrelia burgdorferi infections. Clin Microbiol Rev 1997; 10: 185-201.

[12] Schwaiger M., Peter 0., Cassinotti P.: Routine diagnosis of Borrelia burgdorferi (sensu lato) infections using a real-time PCR assay. Clin Microbiol Infect 2001; 7: 461-469.

[13] Aguero-Rosenfeld M.E.,: Wang G., Schwartz I., et al.: Diagnosis of Lyme Borreliosis. Clin Microbiol Rev 2005; 18: 484-509.

[14] Lebach A.M.: Polymerase chain reactions in diagnosis of Borrelia burgdorferi infections and studies on taxonomic classification. APMIS Suppl 2002; 105: 1-40.

[15] Ruzic-Sabljic E., Lotric-Furlan S., Maraspin V., et al.: Analysis of Borrelia burgdorferi sensu lato isolated from cerebrospinal fluid. APMIS 2001; 109: 707-713.

[16] Oksi J.M., Mariamaki M., Nikoslelainen J., et al.: Borrelia burgdorfer detected by culture and PCR in clinical relapse of disseminated Lyme borreliosis. Ann Med 1999; 31: 225-232.

[17] Priem S., Rittig M.G.,Kamradt T., et al.: An optimized PCR leads to rapid and highly sensitive detection of Borrelia burgdorferi in patients with Lyme borreliosis. J Clin Microbiol 1997; 35: 685-690.

[18] Zbinden R,. , Goldenberger D., Lucchini G.M., et al.: Comparison of two methods for detecting intrathecal synthesis of Borrelia burgdorferi spe-

\section{Correspondence:}

Dr hab.n.med Dorota Dunin-Wąsowicz, Klinika Neurologii i Epileptologii Instytut - "Pomnik-Centrum Zdrowia Dziecka", Aleja Dzieci Polskich 20 email: ddwasowicz@gmail.com cific antibodies and PCR for diagnosis of Lyme neuroborreliosis. $\mathrm{J}$ Clin Microbiol 1994; 32: 1795-1798.

[19] Huppertz H.I., Schmidt H., Karch H.: Detection of Borrelia burgdorferi by nested Polymerase chain reaction in cerebrospinal fluid and urine in children with neuroborreliosis. Eur J Pediatr 1993; 152: 414-417.

[20] Debue M., Gautier P., Hackel C., et al.: Detection of Borrelia burgdorferi in biological samples using the polymerase chain reaction assay. Res Microbiol 1991; 142: 565-572.

[21] Christen H., Eiffert H., Ohlenbusch A., et al.: Evaluation of the polymerase chain reaction for the detection of Borrelia burgdorferi in cerebrospinal fluid of children with peripheral facial palsy. Eur J Pediatr 1995; 154: 374-377.

[22] Nocton J., Dressler F., Rutlegde B.J., et al.: Detection of Borrelia burgdorferi DNA by polymerase chain reaction in cerebrospinal fluid in Lyme neuroborreliosis. J Infect Dis 1996; 174: 623-627.

[23] Amouriaux P., Assous M., Margarrita B., et al.: Polymerase chain reaction with the 30-kb circular plasmoid of Borrelia burgdorferi B 31 as a target for detection of the Lyme borreliosis agends in cerebrospinal fluid. Res Microbiol 1993; 144: 211-219.

[24] Liebling M., Nishio M.J., Rodriguez A., et al.: The polymerase chain reaction for the detection of Borrelia burgdorferi in human body fluids. Arthritis Rheum 1993; $36: 665-675$.

[25] Jaulhac B., Nicolini P., Piemont Y.,et al.: Detection of Borrelia burgdorferi in cerebrospinal fluid of patients with Lyme Borreliosis. N Engl J Med 1993; 324: 1440.

[26] Luft B., Steinman C.R., Neimark H.C., et al.: Invasion of the central nervous system by Borrelia burgdorferi in acute disseminated infection. JAMA 1992; 267:1364-1367.(Erratum,268:872).

[27] Keller T., Halperin J.J., Whitman M., et al.: PCR detection of Borrelia burgdorferi DNA in cerebrospinal fluid of Lyme neuroborreliosis patients. Neurology 1992; 42: 32-42.

[28] Mygland A., Ljostad U., Fingerele V., et al.: European Federation of Neurological Societies.: EFNS guidelines on the diagnosis and management of European Lyme neuroborreliosis. Eur J Neurol. 2010; 17: 8-16.

[29] Coyle P.K, Schutzer S.E. :Neurologic aspects of Lyme disease. Med Clin. North Am. 2002; 86: 261-284.

[30] Almoussa M., Groertzen A., Fanser B., et al.: Stroke as an unusual first presentation of Lyme disease. Case Rep Neurol Med 2015; 389081389084.

[31] Wittwer B., Pelletier S., Ducrocq X., et al.: Cerebrovascular events in Lyme neuroborreliosis .:J Stroke Cerebrovasc Dis 2015; 24: 1671-1678.

[32] Lesser R.L., Kormehl E.W., Pachner A.R.: Neuroophtalmologic manifestation of Lyme disease. Ophtalmology 1990; 97: 699-706.

[33] Waespe N., Steffen I., Heininger U.: Etiology of aseptic meningitis, peripheral facial nerve palsy, and a combination of both in children. Pediatr Infect Dis 2010; 29: 453-456.

[34] Baumann M., Brinbacher R., Koch J., et al.: Uncommon manifestations of neuroborreliosis in children. Eur J Paediatr Neurol 2010; 14: 274-277.

[35] Rocha R., Lisboa L., Neves J., et al.: Neuroborreliosis presenting as acute disseminated encephalomyelitis. Pediatr Emerg Care 2012; 28: 1374-1376.

[36] Horneff G., Huppertzt H.I., Muller K., et al.: Demonstration of Borrelia burgdorferi infection in a child with Giullain-Barré syndrome. Eur J Paediatr 1993;52: 810-812.

[37] Radolović Prenc L., Telarovic S., Vidovic J., et al.: Neuroborreliosis: diagnostic problem in distinguishing from multiple sclerosis. Neurol. Croat. 2014; 63: 1-2.

[38] Schmutzhard E.: Multiple sclerosis and Lyme borreliosis. Wien Klin Wochenschr 2002; 114: 539-543.

[39] Marques A.: Laboratory diagnosis of Lyme disease - advances and challenges. Infect Dis Clin North Am. 2015; 29: 295-307.

[40] Ljostad U., Mygland A. :Chronic Lyme; diagnostic and therapeutic challenges. Acta Neurol Scand Suppl. 2013; 196: 38-47. 